\title{
Cognitive Conflict Strategy Assisted by PhET Simulation to Remediate Student's Misconceptions on Wave Material
}

\author{
*Diajeng Iffatul Hasanah ${ }^{1, ~ a, ~ W a s i s ~}{ }^{2, b}$ \\ ${ }^{1,2}$ Physics Department, Universitas Negeri Surabaya, Jawa Timur, Indonesia \\ adiajeng.17030184019@mhs.unesa.ac.id \\ bwasis@unesa.ac.id
}

\begin{abstract}
ARTICLE INFORMATION
Article History:

Received : :11/12/2020

Revised : :20/12/2020

Accepted : 22/12/2021

Published : 18/01/2021

\section{Keywords:}

Cognitive Conflict Strategy, misconception, PhET

simulation, wave material

\section{DOI:}

https://doi.org/10.46963/asatiz a.v2i1.247

\footnotetext{
*Correspondence Author:

diajeng.17030184019@mhs.u nesa.ac.id
}

\begin{abstract}
In this era, a misconception is one of the biggest challenges in education. Misconception is an understanding of a concept but incompatible with a scientific concept. This research aimed to describe the profile of students' misconceptions and to analyze the decrease of student misconceptions using a cognitive conflict strategy assisted by PhET Simulation. The kind of research is the pre-experimental category with the design of One Group Pre-Test and Post-Test. The sample of this research is a student of XII IPA 2 SMA Negeri 1 Bangkalan. The results of the pre-test showed that the average percentage of students who experience misconception is $53.53 \%$. Based on the pre-test analysis, it was found 20 forms of conceptions that students had regarding the traveling wave material. After being given treatment using a cognitive conflict strategy assisted by PhET simulation, the post-test results of students who experienced misconceptions became $7.65 \%$. There is a decrease in the average percentage of students who experience misconceptions in the pre-test and post-test results. It shows that the cognitive conflict strategy assigned by PhET simulation is effective in remediating the misconceptions of students on wave material.
\end{abstract}

How to cite this article:

Hasanah, D. I., \& Wasis, W. (2021). Cognitive cognitive conflict strategy assisted by PhET simulation to remediate student misconceptions on wave material. Asatiza: Jurnal Pendidikan, 2(1), 19-32. https://doi.org/10.46963/asatiza.v2i1.247.

\section{INTRODUCTION}

The objectives of learning Physics in Senior High Schools (SHS) are following the revised 2013 edition of the Curriculum, students fluent in concepts and principles of Physics. Furthermore, students have the skills to develop knowledge, the confident attitude of students as a provision to continue to the education stage higher level, as well as developing science knowledge and technology (Kemendikbud, 2015). There will be challenges that must be faced by both teachers and learners to achieve learning Physics goals, one of which is a misconception.

Misconceptions are students' understanding of a concept, but this understanding is contrary to scientific concepts (Nurulwati, et.al. 2014). Causative factors that can trigger misconceptions include the level of intelligence and interest in learning possessed by each student, the quality and 
quantity of learning obtained by students, evaluation learning systems, and available learning facilities (Hamid, 2005).

Misconceptions will become dangerous if not handled properly. It is able reduced through remediation. Remediation is a process in learning activities that directed to be able to overcome the learning difficulties of students in various ways, such as changing, improving, or clarifying the thinking framework of students (Tampubolon, 2001). One of the effort ways of remediating misconceptions is to use cognitive conflict strategies where students will experience it that they experience themselves in the process.

The cognitive conflict has a meaning as a conflict that occurs between cognitive structures, namely the organizational structure of knowledge in the brain and the environment, such as an experiment, observation, demonstration, peer discussion, textbooks, or others. It means that cognitive conflict is a conflict that occurs between conceptions in cognitive structures (Lee, et al., 2003). Remediation of misconceptions using cognitive conflict strategy well done by assimilation and accommodation processes. There are three stages of cognitive conflict strategies, namely the preliminary stage (initial phase), the conflict stage (early phase), and the resolution stage (the settlement phase) (Lee, et al. 2003).

Based on research conducted by Maulita et al. (2018) the results obtained after misconceptions remediation using cognitive conflict strategies decreased the average percentage of students' misconceptions by $50.65 \%$. The statement shows that the application of cognitive conflict learning strategies is proven to be effective in remediating students' misconceptions on Archimedes legal material in class VIII of SMP Negeri 5 Pontianak by using a cognitive conflict strategy, the process of assimilation and accommodation shows an overview of the students 'initial conceptions and then given a new explanation that is inversely proportional to or contrary to students' initial conceptions. This matter causes students to change in the thinking process from the initial to the actual scientific concept.

In addition to using cognitive conflict strategy, the learning media used also affects the increasing understanding of concepts and the process of remediating misconceptions experienced by students. The statement by Suhandi, et al. (2008) showed that utilize virtual simulation media in the learning process be able to minimize the number of students who experience misconceptions. Virtual simulation media that can order to in physics learning is PhET Simulation. By using PhET Simulation, students observe the mechanism of physical symptoms in the concept of physics. The advantage of this PhET Simulation is that it can obtain precise and accurate results in data collection. Based on the results of research and discussion researched by Mursalin, it shows that the PhET Simulation model can reduce misconceptions of Physics Education students on the topic of electrical circuits (Mursalin, 2013).

One of the physics concepts that are prone to misconceptions is the wave material. The result of pre-research at 
SMA Negeri 1 Bangkalan underlies the statement that there are still many students who have misconceptions about the traveling wave material. Based on the data, $95.6 \%$ of students at SMA Negeri 1 Bangkalan are wrong in determining examples of traveling wave events in everyday life. In the evaluation of learning, there are still minimal methods and strategies used to reduce the occurrence of misconceptions. Another result states that almost all students have never known about the virtual laboratory of PhET Simulation.

Zulfa et.al (2016) said that at the time of the pretest, the percentage of students who understood the concept was $19.41 \%$, did not understand the concept was $1.76 \%$, did not understand the concept of $29.70 \%$, the misconception was $40.30 \%$, and the percentage of guessing was $8.53 \%$. These results indicate that there are still many students who have misconceptions about the material of Mechanical Waves because students who understand the concept are $<50 \%$. Then also mentioned by Nawati et.al (2017) that based on data from the diagnostic results of students' conception, the average percentage of students who categorized as scientific knowledge was $59.47 \%$, lack of knowledge was $13.6 \%$, error $4.0 \%$, and percentage students experience misconceptions of $22.93 \%$. The results of this data also presented that students still experience misconceptions that occur in mechanical wave material.

Based on the background description regarding the importance of understanding concepts and the dangers of misconceptions in education, it is important to remediate misconceptions for students that still occur in wave material. The advantages to using cognitive conflict strategy assisted by PhET Simulation expected that it be able to remediate the misconceptions experienced by students on the Traveling Wave material in Senior High School (SHS).

\section{METHOD}

This type of research is the preexperimental category with the design of the One Group Pre-Test and Post Test. The following is the research design used in this experiment

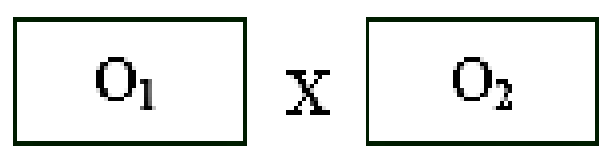

Figure 1. The research design (Arikunto, 2010)

$\mathrm{O}_{1}$ : Observation before the experiment

$\mathrm{O}_{2}$ : Observation after the experiment

$\mathrm{X}$ : Treatment given (cognitive conflict strategy assisted by PhET Simulation).

In this study, the population was class XII students at SMA Negeri 1 Bangkalan who had received the traveling wave material before. XII IPA $2(\mathrm{~N}=34)$ was selected as the research sample through a whole group random sampling technique.

The data collection technique used a multiple-choice diagnostic test for open reasons. In this diagnostic test, there are five indicators are used with conceptual questions. There is no need to use quantitative calculations to answer questions. The indicators used in this study are: 1) Students can detect traveling wave 
events in everyday life; 2) Students can analyze the effect of changes in frequency and amplitude on sound waves; 3) Students can analyze the effect of changes in frequency and amplitude on water waves; 4) Students can analyze the effect of changes in frequency and amplitude on light waves; 5) Students can analyze factors that affect the amount of wave energy. Each indicator represents one provided question. The students' answer data analyzed according to the assessment criteria grouped into categories of misconceptions, conceptual understanding, and conceptual misunderstanding.

The other data collection technique is an interview. Interviews are used as communication media with students who are the research samples. Interviews are used to know the causes of students experiencing misconceptions. The interviews conducted in this study were unstructured interviews, which were independent interviews where the researcher did not use interview guidelines that have a systematic and complete structure for data collection (Sugiyono, 2013).

To analyze the profile of students' misconceptions, this study used a threelevel multiple-choice diagnostic test with the CRI (Certainly of Response Index) approach method with a scale of 1-4 developed by Nursiwin (2014) The CRI is used to classify students according to their answers. The interpretation of the CRI scale is shown in table 1.
Table 1. CRI Scale

\begin{tabular}{cc}
\hline CRI & Criteria \\
\hline $\mathbf{1}$ & Very not sure \\
\hline $\mathbf{2}$ & Not sure \\
\hline $\mathbf{3}$ & Sure \\
\hline $\mathbf{4}$ & Very sure \\
\hline
\end{tabular}

The categories of interpretation of the CRI scale are as follows

\section{1. $>2$ is a high-level CRI}

2. $\leq 2$ is a low-level CRI

This study uses the t-test to determine the effect of the results before being given treatment and after being given treatment. The t-test uses to determine the difference between the two means of the posttest or pretest. According to Sudjana (2005) to test the above hypothesis, the t-test statistical formula can be used, namely:

$$
t=\frac{\overline{x_{1}}-\overline{x_{2}}}{s \sqrt{\frac{1}{n_{1}}}+\frac{1}{n_{2}}}
$$

Where,

$$
s=\sqrt{\frac{\left(n_{1}-1\right) s_{1}^{2}+\left(n_{2}-1\right) s_{2}^{2}}{n_{1}+n_{2}-2}}
$$

$\mathrm{t}=\mathrm{t}$-test

$\mathrm{s} \quad=$ Standard deviation

$\overline{x_{1}}=$ Averagepost-test

$\overline{x_{2}}=$ Average pre-test

$n_{1}=$ Number of post-test samples

$n_{2}=$ Number of pre-test samples

$s_{1}^{2}=$ post-testStandard deviation

$s_{2}^{2}=$ pre-test Standard deviation

The procedure used in this study consists of three stages, namely: 1) The preparation stage; 2) The implementation Stage; 3) The final Stage. 


\section{The Preparation Stages}

The steps taken at this preparation stage include: (1) Conducting literature studies from various relevant sources; (2) Conducting observations at SMA Negeri 1 Bangkalan; (3) Determine the problem in research according to the results of observations; (4) Making research question instruments; (5) Validating question instruments and revisions; (6) Submit a research permit to the Physics Department of Universitas Negeri Surabaya.

\section{The Implementation Stages}

The steps taken at the implementation stage are: (1) Providing pre-test questions to students to analyze the profile of students' conception of the traveling wave and determine how many students experience misconceptions; (2) remediation in the form of treatment using cognitive conflict strategies assisted by PhET Simulation on students who experience misconceptions; (3) Carry out a post-test assessment of students to analyze the decrease in the number of students who experience misconceptions.

\section{The Final Stage}

The steps at this stage consist of: (1) Processing and analyzing the results of the students' pre-test and post-test; (2) Presenting the results of the data obtained to answer the formulation of the problem in the form of tables, graphs, to a description of the explanation and thenconcluding the research; (3) Prepare research reports; (4) Publish the research reports by online; (5) Give a report to the school as consideration for learning in the school.

\section{RESULT AND DISCUSSION}

Based on this research, the sample data has obtained either pre-test and posttest as many as 34 students from XII IPA 2 SMA Negeri 1 Bangkalan. The analysis research overall succinctly showed in table 2.

Table 2.

The distribution of the number of students who experienced misconception

\begin{tabular}{|c|c|c|c|c|c|c|}
\hline \multirow[b]{2}{*}{ Indicator } & \multicolumn{3}{|c|}{ Pre-Test } & \multicolumn{3}{|c|}{ Post-Test } \\
\hline & $\sum_{\text {Wrong }}$ & $\sum_{\text {Mis }}$ & $\begin{array}{c}\% \\
\text { Mis }\end{array}$ & $\sum_{\text {Wrong }}$ & $\sum_{\text {Mis }}$ & $\begin{array}{c}\% \\
\text { Mis }\end{array}$ \\
\hline Indicator I & 33 & 26 & $76,47 \%$ & 1 & 1 & $2,94 \%$ \\
\hline Indicator II & 26 & 14 & $41,18 \%$ & 2 & 2 & $5,88 \%$ \\
\hline Indicator III & 23 & 19 & $55,88 \%$ & 4 & 4 & $11,76 \%$ \\
\hline Indicator IV & 32 & 16 & $47,06 \%$ & 3 & 3 & $8,82 \%$ \\
\hline Indicator V & 24 & 16 & $47,06 \%$ & 3 & 3 & $8,82 \%$ \\
\hline Average & & & $53,53 \%$ & & & $6,75 \%$ \\
\hline
\end{tabular}


Cognitive Conflict Strategy Assisted by PhET Simulation to Remediate Student's Misconceptions on Wave Material

Based on table 2, before being given the cognitive conflict strategy assisted by PhET Simulation treatment, the pre-test results showed that students experienced misconceptions on all indicators of the traveling wave material. Indicator $\mathrm{I}$ is detecting traveling wave events in daily life. There are 26 students $(76.47 \%)$ who experience misconceptions. Indicator II is to analyze the effect of changes in frequency and amplitude on sound waves. In this indicator, there are 14 students (41.18\%) who experience misconceptions. Indicator III is to analyze the impact of changes in frequency and amplitude on water waves. For indicator III, there are 19 students (55.58\%) who experience misconceptions. Indicator IV explains the effect of changes in frequency and amplitude on light waves. In Indicator IV, there are 16 students (47.06\%) who experience misconceptions. Indicator $\mathrm{V}$ is analyzing the factors that affect the amount of wave energy. And for indicator $\mathrm{V}$, there are 16 students $(47.06 \%)$ who experience misconceptions. The average percentage of students who experience misconceptions in the five indicators is $53.53 \%$.
After being given treatment using cognitive conflict strategies assisted by PhET Simulation, the post-test results showed a significant decrease in the percentage of misconceptions. The percentage decrease of students who experience misconceptions in indicator I is $2.94 \%$. Then the Percentage decrease of students who experience misconceptions in indicator II becomes $5.88 \%$. Furthermore, the percentage decrease of students who experience misconceptions in indicator III is $11.76 \%$. The percentage decrease of students who experience misconceptions on indicator IV becomes $8.82 \%$. And the last, the percentage decrease of students who experience misconceptions in indicator $\mathrm{V}$ is $8.82 \%$. It means that the difference between the average percentage before and after being given treatment is $45.88 \%$.

Based on the analysis of students' answers, there are several different conceptions founded in understanding the traveling wave material. The different conceptions founded in every indicator of the questions tested. The forms of students' conception are shown in table 3.

Table 3.

Profile of Student Misconceptions

\begin{tabular}{|c|c|c|c|c|c|}
\hline \multirow{2}{*}{ Indicator } & \multirow{2}{*}{ Form of conception } & \multicolumn{2}{|c|}{ Pre-Test } & \multicolumn{2}{|c|}{ Post-Test } \\
\hline & & $\mathbf{n}$ & $\%$ & $\mathbf{n}$ & $\%$ \\
\hline \multirow{5}{*}{ I } & Misconception & & & & \\
\hline & $\begin{array}{l}\text { The example of a traveling wave is the same as } \\
\text { when vibrating the strings on a guitar. }\end{array}$ & 6 & $17,65 \%$ & 1 & $2,94 \%$ \\
\hline & Misconception & & & & \\
\hline & $\begin{array}{l}\text { Light waves are not included in the traveling } \\
\text { waves because it does not cause vibrations. }\end{array}$ & 22 & $64,71 \%$ & 0 & $0 \%$ \\
\hline & Misconception & 3 & $8,82 \%$ & 0 & $0 \%$ \\
\hline
\end{tabular}




\begin{tabular}{|c|c|c|c|c|c|}
\hline \multirow{7}{*}{ Indicator } & \multirow{2}{*}{ Form of conception } & \multicolumn{2}{|c|}{ Pre-Test } & \multicolumn{2}{|c|}{ Post-Test } \\
\hline & & $\mathbf{n}$ & $\%$ & $\mathbf{n}$ & $\%$ \\
\hline & $\begin{array}{l}\text { Water waves are not included in the traveling } \\
\text { wave because they cannot move. }\end{array}$ & & & & \\
\hline & Misconception & & & & \\
\hline & $\begin{array}{l}\text { Sound is not a traveling wave because it does not } \\
\text { produce waves. }\end{array}$ & 2 & $5,88 \%$ & 0 & $0 \%$ \\
\hline & Scientific Conception & & & & \\
\hline & $\begin{array}{l}\text { The examples of a traveling wave events in daily } \\
\text { life are sound, water, and light waves. }\end{array}$ & 1 & $2,94 \%$ & 33 & $97,06 \%$ \\
\hline \multirow{7}{*}{ II } & Misconception & & & & \\
\hline & $\begin{array}{l}\text { The frequency of sound waves affects how loud } \\
\text { the sound is produced. }\end{array}$ & 15 & $44,12 \%$ & 2 & $5,82 \%$ \\
\hline & Misconception & & & & \\
\hline & $\begin{array}{l}\text { The car in this situation doesn't move, so the } \\
\text { sound is slower. }\end{array}$ & 1 & $2,94 \%$ & 0 & $0 \%$ \\
\hline & Misconception & & & & \\
\hline & $\begin{array}{l}\text { Amplitude affects whether the sounds are } \\
\text { identical or not. }\end{array}$ & 10 & $29,41 \%$ & 0 & $0 \%$ \\
\hline & $\begin{array}{l}\text { Scientific Conception } \\
\text { In sound waves, frequency shows the level of the } \\
\text { sound scale, while amplitude shows the loudness } \\
\text { of the sound. }\end{array}$ & 8 & $23,53 \%$ & 32 & $94,12 \%$ \\
\hline \multirow{3}{*}{ III } & $\begin{array}{l}\text { Misconception } \\
\text { The amplitude of the water wave affects the } \\
\text { vibrations or ripples of the water produced. }\end{array}$ & 22 & $64,71 \%$ & 4 & $11,76 \%$ \\
\hline & $\begin{array}{l}\text { Misconception } \\
\text { The mass of the rock affects the resulting water } \\
\text { ripples. }\end{array}$ & 1 & $2,94 \%$ & 0 & $0 \%$ \\
\hline & $\begin{array}{l}\text { Scientific Conception } \\
\text { In water waves, the frequency indicates how } \\
\text { much water ripples are formed. Meanwhile, the } \\
\text { amplitude shows the level (high or low) of the } \\
\text { wave. }\end{array}$ & 11 & $32,35 \%$ & 30 & $88,23 \%$ \\
\hline \multirow{4}{*}{ IV } & $\begin{array}{l}\text { Misconception } \\
\text { The frequency of the light waves affects the } \\
\text { intensity of the light in the flashlight. }\end{array}$ & 29 & $85,30 \%$ & 3 & $8,82 \%$ \\
\hline & $\begin{array}{l}\text { Misconception } \\
\text { Light intensity is affected by the battery energy } \\
\text { in the flashlight. }\end{array}$ & 3 & $8,82 \%$ & 0 & $0 \%$ \\
\hline & $\begin{array}{l}\text { Misconception } \\
\text { Fast propagation affects the intensity } \\
\text { (brightness) of light produced by the flashlight. }\end{array}$ & 1 & $2,94 \%$ & 0 & $0 \%$ \\
\hline & $\begin{array}{l}\text { Scientific Conception } \\
\text { In light waves, frequency indicates the color of } \\
\text { visible light, while amplitude indicates the level } \\
\text { of light brightness (intensity). }\end{array}$ & 1 & $2,94 \%$ & 31 & $91,18 \%$ \\
\hline
\end{tabular}




\begin{tabular}{|c|c|c|c|c|c|}
\hline \multirow{2}{*}{ Indicator } & \multirow{2}{*}{ Form of conception } & \multicolumn{2}{|c|}{ Pre-Test } & \multicolumn{2}{|c|}{ Post-Test } \\
\hline & & $\mathbf{n}$ & $\%$ & $\mathbf{n}$ & $\%$ \\
\hline \multirow{8}{*}{$\mathbf{V}$} & Misconception & & & & \\
\hline & $\begin{array}{l}\text { Particle energy is influenced by the type and } \\
\text { shape of the particles. }\end{array}$ & 19 & $55,88 \%$ & 1 & $2,94 \%$ \\
\hline & Misconception & & & & \\
\hline & $\begin{array}{l}\text { The water ripples produced by the rock are } \\
\text { bigger so that the energy is greater. }\end{array}$ & 4 & $11,75 \%$ & 0 & $0 \%$ \\
\hline & Misconception & & & & \\
\hline & $\begin{array}{l}\text { Rocks and leaves have no energy because their } \\
\text { mass is so small. }\end{array}$ & 1 & $2,94 \%$ & 2 & $5,88 \%$ \\
\hline & Scientific Conception & & & & \\
\hline & $\begin{array}{l}\text { The amount of wave energy is influenced by the } \\
\text { amplitude, frequency, and mass of the particles. } \\
\text { If there are different particles but the amplitude, } \\
\text { frequency, and mass of the particles are the same, } \\
\text { the wave energy is the same. }\end{array}$ & 10 & $29,41 \%$ & 31 & $91,18 \%$ \\
\hline
\end{tabular}

There are 20 forms of a students' conception found in the study. 5 of 20 are scientific conceptions, while the rest are misconceptions. The most diverse form of conception is found in indicators I. It has five forms of conception. Meanwhile, the least form of conception is in indicator III, which has three forms of conception.

The data table 3 . clearly shows if there is a decrease in misconceptions experienced by students. The data also shows an increase in students' understanding of scientific conceptions. Based on the pre-test and post-test analysis, the test results obtained are $91,29 \%$. The N-Gain Value is included in the high category. It shows that treatment using a cognitive conflict strategy assisted by PhET Simulation is effective in remediating students' misconceptions on Traveling wave material.

The results and invention obtained from this study say that students still experience misconceptions about the traveling wave material that has been taught in school. It can be observed that on average students' percentage who experience misconceptions are $53.53 \%$. The outline shows that students experience misconceptions presumably because the physics learning process in schools still uses conventional teacher-centered learning methods so that students do not have the opportunity to develop their understanding.

Another finding from this study is that there are 20 forms of conceptions that students have on traveling wave material. This situation is fascinating because the conceptions of students are very diverse even though they are within the scope of one class. It happens because the traveling wave material is included in abstract physics and the material taught cannot be seen directly without the media.

The first indicator, students can detect Traveling Waves in everyday life. Total students who experienced misconceptions were $76.47 \%$. The most common form of conception is that 
students assume that light waves are not included as traveling waves because they do not cause vibrations. This form of conception is incorrect because the scientific conception is that light waves are examples of traveling waves. Apart from light waves, there are also water waves and sound waves. This wrong form of conception is because students at the time of implementing learning about the traveling wave material, no learning media is used. It causes students to receive incomplete information.

Another form of misconception is that students assume that Traveling Waves are, for example, the same as when vibrating a string on a guitar, and water/sound waves are not a traveling wave. It happens to be caused by wrong intuition when student spontaneously expressing their ideas based on their inner feelings without thinking objectively and rationally (Yusran, 2017).

The second indicator, students analyze the effect of changes in the frequency and amplitude of sound waves. The total of students who experienced misconceptions was $41.18 \%$. Most of the students think that the frequency of sound waves affects the loudness of the sound produced. This finding was also stated by Widiastuti et.al (2019) that students experience a misconception by assuming that the high-low of sound waves is the same as the loudness of sound waves. So that students think if the frequency is getting higher/lower, it will affect the loudness of the sound produced. This form of conception is incorrect because the scientific conception of sound waves, frequency indicates the high-low of the sound scale, while amplitude indicates the loudness of the sound. It is due to the humanistic thoughts possessed by students Nurulwati et.al (2014).

Another form of misconception contained in indicator II is that students assume that the amplitude affects whether the sound is identical or not. Another form of the wrong conception says that students think that the sound from the car will not be heard because the car is not moving. This is allegedly due It happens because students are still hesitant to determine which one is more influential between the frequency or amplitude in sound waves.

The third indicator is the students analyze the influence of frequency and amplitude on water waves. The total of students who experienced misconceptions was $55.88 \%$. In this indicator, the most common form of conception is the student's think that the amplitude of the water wave affects the vibrations or ripples of the water produced. This expression is a form of the wrong conception because, in water waves, the frequency indicates how much water ripples are formed. While the amplitude shows the level of the waves formed. Another form of misconception is that students think that rock mass affects the water ripples produced. The cause of students experiencing misconceptions on this indicator is the incomplete reasoning of students due to the absence of learning media used to make students think concretely.

The fourth indicator in this study aimed at analyzing how much students understand the effect of frequency and amplitude on light waves. Students who experience misconceptions are $47.06 \%$. 
The most commonly mentioned form of conception is that the frequency of the light waves affects the intensity of the light in the flashlight. It is a misconception because the frequency of the light waves shows the visible color, while the amplitude shows the light intensity. Based on the results of the interview, the factor causing this misconception was due to the provision of material that was too fast so that students were not yet perfect in processing their understanding of light waves.

The fifth indicator aimed at analyzing the factors that affect the amount of wave energy. On this indicator, $55.88 \%$ of students experience misconceptions. The most common form of conception is that students assume that the energy of particles is influenced by the type and shape of objects' material. This conception is wrong because the amount of wave energy is influenced by the amplitude, frequency, and mass of the particles. If there are different particles but the amplitude, frequency, and mass of the particles are the same, the wave energy is the same. Another form of conception is that students assume that the mass of rocks and leaves is too small so that is impossible to have the energy of particles. Based on the results of the interview, the cause of this misconception is students are only limited to knowing the wave energy formula with knowing the concept of the formula.

The study in detail reveals the form of conception that students have on the traveling wave material and the causes of these students experiencing misconceptions. The cause of students experiencing misconceptions, in general, is due to the learning methods that are not appropriate to use in this material. Humanistic thinking can also influence students' conceptual understanding of the traveling wave material.In addition, the lack of learning media causes students to experience incomplete reasoning.It has shown when students only know the formula used without knowing the meaning of the concepts in the formula.

Based on the pre-test results, the average percentage of students who experienced misconceptions was $53.53 \%$. Then the post-test results showed a decrease in the average percentage to be $7,65 \%$. The data analysis showed that if there were students who experienced misconceptions during the pre-test, they were able to answer correctly during the post-test. To see the difference between the pre-test and post-test results is clearly shown in Figure 2. 
Figure 2.

Graph of the average of students who experience misconceptions during the pre-test and post-test.

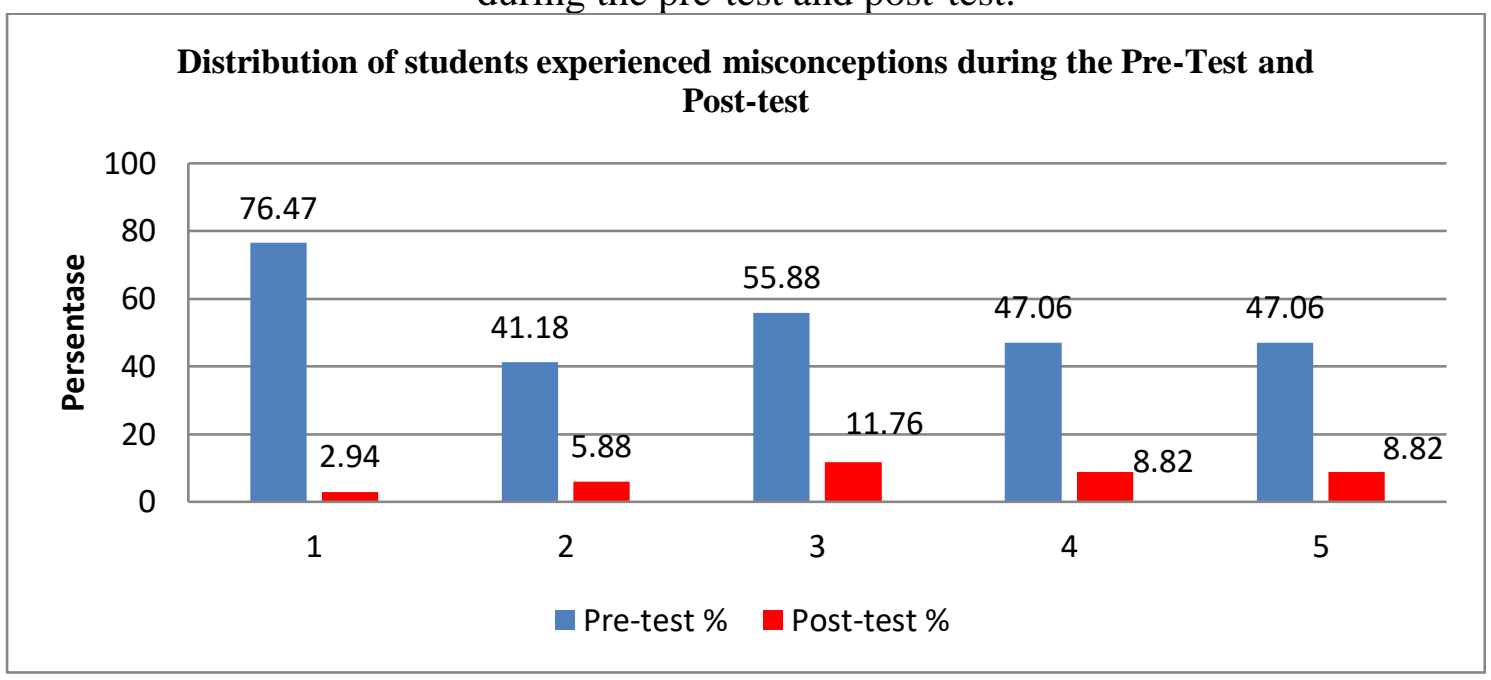

Based on Figure 2. The graph of students who experienced misconceptions during the pre-test and post-test experienced a decrease in each indicator. These results prove that giving treatment using cognitive conflict strategy learning methods assisted by PhET Simulation can remediate misconceptions that exist in students. This is also reinforced by the $\mathrm{t}$ test value of 100 , where the t-test value is $14,577>2,042$ t-test table value. Based on the t-test value, there are differences in the results obtained before and after treatment is given. Then for the $\mathrm{N}$-Gain value in this study was $91,29 \%$. This $\mathrm{N}$-Gain value is included in the high category so that the effect of the treatment is effective to remediate the misconceptions that students have.

However, there are still students who experience misconceptions after being given remediation activities. This condition happens because depending on the individual student; the motivation of students in participating in learning physics is still lacking. This statement is also mentioned by Yusran (2017) if there are students who experience misconceptions after being given remediation activities, allegedly occur due to participants who are not focused and have low interest in learning in listening to the material presented by the researcher.

The cognitive conflict strategy is used as an effort to remediation misconceptions. The cognitive conflict strategy in this study aims to change students' initial perceptions that do not fit the concept. The learning method used is to provide a condition in the form of dissatisfaction caused by a conflict between the new information obtained and the perceptions that already have in the cognitive structure of students. This situation is expected so that students can change their views and thoughts by new knowledge and by scientific concepts Ma'rifah et.al (2012).

In the process of implementing remediation, some students tend to follow 
their initial conception. Because not all new conceptions are contrary to these initial conceptions accepted by students. This situation causes there are still students who experience misconceptions. This statement is analogous to Yusran (2017), that are some students still experience misconceptions after the remediation process because these students tend to retain their initial conceptions.

The utilization of PhET Simulation media also important in the process of remediating students' misconceptions. It happens because using PhET Simulation can be a medium for students to complement their reasoning. With PhET Simulation, students can do fun and interest learning intellectually so that students can quickly understand the concepts given. Research conducted by (Mursalin, 2013) concluded that the learning model using the PhET Simulation assisted by worksheets can be used to remediate and minimize student misconceptions. It is also reinforced by the statement Yuafi and Endryansyah (2015) if there is a change in value for the better by the application of a direct learning model that uses Physics Education Technology (PhET) Simulation learning media on student learning outcomes.

\section{CONCLUSION}

The purpose of this study is to describe the profile of students'misconceptions on the traveling wave material and to analyze the effectiveness of cognitive conflict strategy assisted by PhET Simulation to remediate students' misconceptions on wave material. The results of the data show that the average percentage of students who experience misconceptions is $53.53 \%$. Data analysis on the pre-test found as many as 20 forms of conceptions that were owned by students. After being given learning treatment using a cognitive conflict strategy assisted by PhET Simulation, there was a decrease in the average percentage of students who experienced misconceptions to $10 \%$. It shows that the cognitive conflict strategy assisted by PhET Simulation is an effective effort to remediate the misconceptions of students on wave material.

\section{ACKNOWLEDGMENT}

I am very grateful to Allah SWT for all the conveniences and streght provided in completing my research. I wish to express my deep thanks to professor Wasis as my guide for continuous encouragement, good advice during my study, and I thank the students of class XII IPA 2 SMA Negeri 1 Bangkalan for their help and cooperation. I am thankful to all the members of the Department of physics Universitas Negeri Surabaya for their kindness and helps with my study. Finally, I am indebted to my lovely parents, my sister, my brother, and my best friends for their continuous support and encouragement for my pursuit.

\section{REFERENCES}

Arikunto, S. (2010). Prosedur Penelitian Suatu Pendekatan Praktik. Yogyakarta: Rineka Cipta.

Hamid, A. A. (2005). Salah Konsepsi Fisika dan Faktor-Faktor yang Mempengaruhinya. Seminar Nasional Penelitian, Pendidikan \& Penerapan MIPA. 
Kemendikbud. (2015). Materi Pelatihan Implementasi Kurikulum Jenjang SMA/SMK. Badan Pengembangan SDM Pendidikan, Kebudayaan dan Penjaminan Mutu Pendidikan.

Lee, G., Kwon, J., Park, S.-S., Kim, J.W., Kwon, H.-G., \& Park, H.-K. (2003). Development of an Instrument for Measuring Cognitive Conflict in Secondary-Level Science Classes. Journal of Research in Science Teaching, 40(6), 585-603. https://doi.org/10.1002/tea.10099.

Maulita, S. R., Sitompul, S.S., Mursyid, S. (2018). Efektivitas remediasi miskonsepsi siswa menggunakan strategi konflik kognitif pada materi hukum Archimedes di SMP. Jurnal Pendidikan dan Pembelajaran Khatulistiwa, 7(7), 9-18. https://jurnal.untan.ac.id/index.php/j pdpb/article/view/26758

Ma'rifah, M., Sumarni, W., Siadi, K. (2012). Keefektifan pereduksian miskonsepsi melalui strategi konflik kognitif pada pemahaman konseptual dan algoritmik. Chemistry in Education, 2(1), 42-48. https://journal.unnes.ac.id/sju/index. php/chemined/article/view/979

Mursalin, M. (2013). Model remediasi miskonsepsi materi rangkaian listrik dengan pendekatan simulasi PhET. Jurnal Pendidikan Fisika Indonesia, 9(1). 1-7. https://doi.org/10.15294/jpfi.v9i1.25 74

Nawati, I., Saepuzaman, D., Suhandi, A. (2017). Konsistensi konsepsi siswa melalui penerapan model interactive lecture demonstration pada materi gelombang mekanik. Jurnal Penelitian Pembelajaran Fisika, 8(1),
32-38.

https://doi.org/10.26877/jp2f.v8i1.13 34

Nursiwin. (2014). Menggali miskonsepsi siswa pada materi perhitungan Kimia menggunakan certainty of response. Jurnal Pendidikan dan Pembelajaran Khatulistiwa, 3(1), 111. https://jurnal.untan.ac.id/index.php/j pdpb/article/view/4428

Nurulwati, N., Veloo, A., Ali, R M. (2014). Suatu tinjauan tentang jenisjenis dan penyebab miskonsepsi Fisika. Jurnal Pendidikan Sains Indonesia, 2(1), 87-95. http://jurnal.unsyiah.ac.id/JPSI/articl e/view/7636

Sudjana. (2005). Metoda Statistika. Bandung: Tarsito.

Sugiyono. (2013). Metode Penelitian Kuantitatif dan R \& D. Bandung: Alfabeta.

Suhandi, A., Sinaga, P., Kaniawati I., Suhendi, E. (2008). Efektivitas penggunaan media simulasi virtual pada pendekatan pembelajaran konseptual interaktif dalam meningkatkan pemahaman konsep dan meminimalkan miskonsepsi. Jurnal Pengajaran Matematika dan Ilmu Pengetahuan Alam. 13(1).

Tampubolon, T. (2001). Meningkatkan hasil belajar gelombang kelas il B cawu II SLTPN 13 Medan melalui pembelajaran Fisika model kontruktivis. Jurnal Pendidikan Science. 25(1). 30-39.

Widiastuti, A. S., Purwanto, J. (2019). Remediasi miskonsepsi pada materi gelombang bunyi dengan pendekatan konstruktivisme Metode 5E di SMA N 1 Turi. Prosiding SNFA Seminar Nasional Fisika dan Aplikasinya. 
https://jurnal.uns.ac.id/prosidingsnfa /article/view/35909

Yuafi, M. E. D., \& Endryansyah, E. (2015). Pengaruh penerapan media pembelajaran PhET (Physics Education Technology) simulation terhadap hasil belajar siswa Kelas X TITL pada standar kompetensi mengaplikasikan rangkaian listrik di SMKN 7 Surabaya. Jurnal Pendidikan Teknik Elektro, 4(2), 407-414.

Yusran, Y. (2017). Remediasi miskonsepsi siswa menggunakan strategi konflik kognitif berbantuan simulasi Phet tentang rangkaian listrik di SMA. Jurnal Pendidikan dan Pembelajaran Untan, 6(5). Retrieved From https://jurnal.untan.ac.id/index.php/j pdpb/article/download/20121/16513

Zulfa, I., Setyarsih, W., Mukhayyarotin N. R. J. (2016). Dampak penerapan model pembelajaran interactive demonstration terhadap reduksi miskonsepsi siswa pada materi gelombang mekanik. Jurnal Inovasi Pendidikan Fisika, 5(3), 178-183 Retrieved fromhttps://jurnalmahasiswa.unesa.a c.id/index.php/inovasipendidikanfisika/article/view/21170 $1 / 19892$ 